\title{
The Diatom Community in Maluk Coastal Water in West Sumbawa
}

\author{
Eti Komalasari \\ Biology Education Study Program \\ Universitas Mataram \\ Mataram, Indonesia
}

\author{
K Khairuddin* \\ Biology Education Study Program \\ Universitas Mataram \\ Mataram, Indonesia \\ khairuddin.fkip@unram.ac.id
}

\author{
Lalu Japa \\ Biology Education Study Program \\ Universitas Mataram \\ Mataram, Indonesia
}

\begin{abstract}
The existence of diatoms greatly affects the life in the water as it plays some important roles as a source of food for various organisms in aquatic ecosystems. In addition, the diatoms existence is commonly used as an environmental bioindicator. The purpose of this study was to determine the diatom community structure in the Maluk Coastal waters. The water sample was taken from three coastal waters areas by using plankton net of $20 \mu \mathrm{m}$ in size and there thirty-eight diatom species were identified. Data of diatom community were analyzed by using parameters of density, species diversity index, species evenness index, and values of importance for diatom species. The density of diatom in all sampling sites is 1600 ind./L. Five species of diatoms that have the highest density were Asteroplanus karianus (573.333 ind./L), Thalassiothrix longissima (423.333 ind./L), Striatella unipunctata (130 ind / L), Gyrosigma scalprum (50 ind / L), and Licmophora abbreviate (40 ind/L). The diversity index value of the diatom species was in moderate category (1.964). Asteroplanus karianus was a species that can be found in all three sampling sites and with the highest value of importance of $40.751 \%$. The diatom species evenness index was 0.522 , which means that the diatom species were not distributed evenly, because there were several species dominating with a large number of individuals at certain sampling sites.
\end{abstract}

Keywords - community, diatom, Maluk coastal water

\section{INTRODUCTION}

Coastal ecosystems are dynamic ecosystems and have a variety of diverse habitats and have enormous biological potential resource. One of the most important biological resources in the presence of marine ecosystems is phytoplankton, especially diatoms [1]. Diatoms as a component of phytoplankton are functioning as primary sources for aquatic ecosystems.

The existence of diatoms greatly affects the life in the coastal waters because the diatoms play an important role not only as the source of food for various marine organisms but also in the transfer of carbon, nitrogen and phosphate. Changes in the function of waters were caused by some factors coming not only from the nature but also from human activities. These changes often results in the changes in the structure and quantitative value of microalgae, especially diatoms because these organisms have varied responses, ranging from very vulnerable to high tolerance to any conditions that occur in the coastal waters and diatoms are one of the organisms commonly used as an environmental bio-indicator [2]. Diatoms are very effective and economical bio-indicators for environmental changes because they have several advantages compared to other organisms, in which diatoms have wide distribution with varied populations, have the important role in the food chain and short life cycle, they are fast reproducing and are found in almost all substrates so that they are able to record the history of their habitat, many of their species are sensitive to environmental changes so that they are quick to respond, able to reflect changes in water quality in the short and long terms, and they are easy in sampling, analysis and identification [3]. This study would like to discover how the structure of the diatom species community in the coastal waters in Maluk, West Sumbawa is, which was analyzed by using density parameters, species diversity index, species evenness index, and the value of importance.

\section{RESEARCH METHOD}

Seawater samples were taken at 3 points on the coastal waters of Maluk, West Sumbawa in July 2018. Samples were taken by filtering 100 liters of seawater by using a 20 micron-meter plankton net. Samples were preserved with formalin at a preservation concentration of $4 \%$. Observation and identification of diatom species were carried out at the Biology Laboratory of FMIPA the university of Mataram. Diatom species identification is done morphologically [4] based on sources written by [5], [6], [7], [8], and [9].

\section{RESULTS AND DISCUSSION}

Thirty-eight diatom species were identified in the Maluk Coastal waters. It showed that the sampling point III has the largest population of 33 species. Whereas, at sampling points I and II there are 10 and 18 species, respectively (Figure 1).

The number of diatom species found in Maluk Beach is 38 species, higher if compared to 26 diatom species found in Jeranjang Beach [10] and 31 diatom species found in Dumai coastal waters, Riau [2]. But this number is fewer than 70, the number of diatom species found in the waters of the North, East, and South Beaches of Lombok Island [11], and 74 species in the Mangrove Waters of the Gili Sulat East Lombok Habitat [12]. It is found that 6 out of the 38 species spreading throughout the study sites are Asteroplanus karianus, Climatosphenia moniligera, Coscinodiscus radiatus, Navicula lyra, Striatella unipunctata, and Thalassiothrix longissima. 


\section{Number Species}

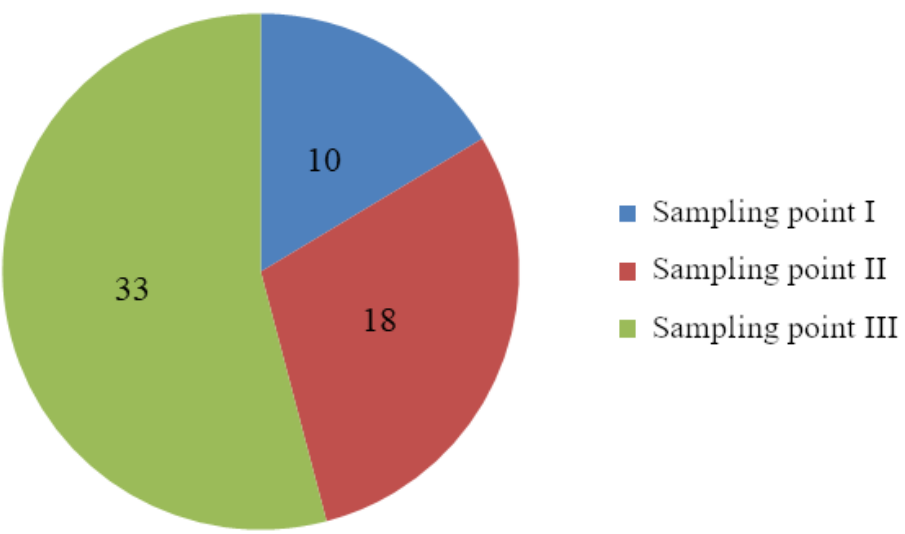

Fig. 1. Comparison of the Number of Diatom Species Taxonomy

\section{A. The Diatom Species Density}

The total diatom density in the Maluk coastal waters is 1,600 individuals / liter. Diatom density at each of the highest sampling points is at sampling point III, which is 1163.333 ind / L while at sampling points I and II are 136,667 ind / L and 350,000 ind / L, respectively. The average \pm SD diatom density at the three sampling areas (I, II, and III) of research was $1 \pm 10,541$ ind / L, 19,444 \pm 32,000 ind $/ \mathrm{L}$, and $32,253 \pm 97,951$, respectively. The comparison of the average density of diatoms at each point of the study site can be seen in Figure 2 .

The diatom species that have the highest density are Asteroplanus karianus with density of 573,333 ind / L, Thalassiothrix longissima has 423,333 ind / L density, Striatella unipunctata has 130 ind / L density, Gyrosigma scalprum has 50 ind / L density, and Licmophora minimate has 40 ind / L density. Whereas Camphylodiscus undulates, Cocconeis scutellum, Grammatophora marina, Mastogloia decussate, Navicula membranacea, Nitzchia frequens, Odontella aurita, Rhabdonema adriaticum, Rhizosolenia alata, and Triceratium reticulum are diatom species which have 3.333 ind / L, the lowest density.
The species that have the highest density is assumed to be caused by the physical chemistry factors of the waters, so the organic matter content is high. The large amount of dissolved inorganic nitrogen and dissolved phosphorus also causes the high density of Asteroplanus karianus. According to [13], dissolved inorganic nitrogen and dissolved inorganic phosphorus are significantly lower in the areas where Asteroplanus karianus breeds and this causes nutritional deficiencies for Pyropia.

Study findings [14] indicate that in Ariake coastal waters, Japan Asteroplanus karianus is a dangerous diatom species because it can cause bleaching in Pyropia. Field study findings show that A. karianus causes red tides only in winter on most beaches, such as the western and eastern waters of the Dutch coastal waters, Baltic coastal waters, and Ariake coastal waters. Nonetheless, laboratory study findings show that the growth rate of A. karianus is higher within condition of high water temperature than that low water temperature. However, A. karianus does not grow well at $30^{\circ} \mathrm{C}[13]$, meanwhile the water temperature in the Maluk coast at the time of the study was $25^{\circ} \mathrm{C}$.

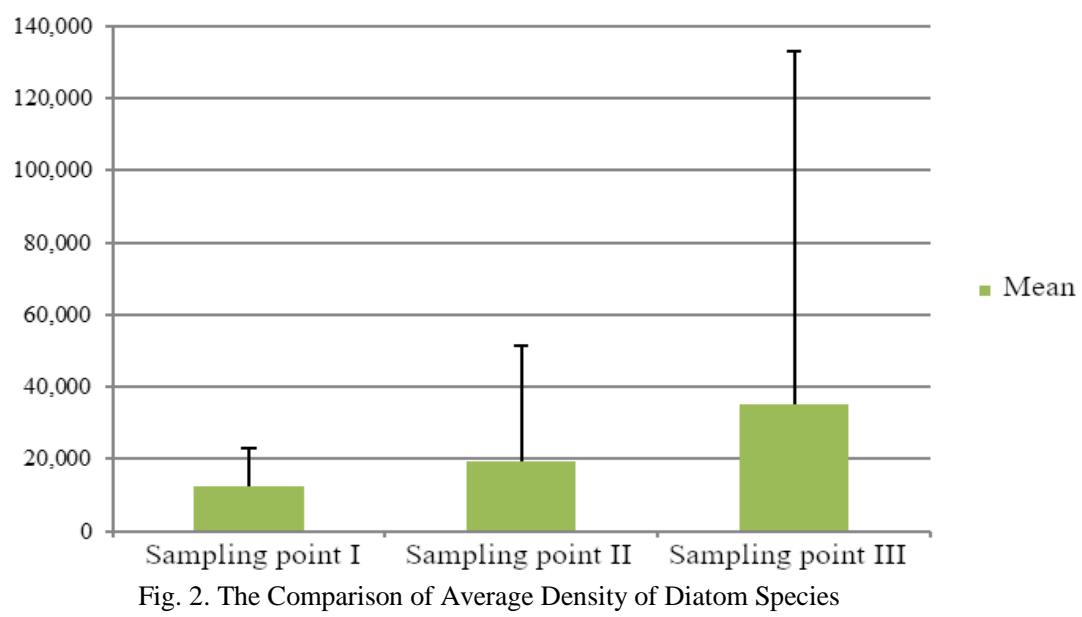




\section{B. The Species Diversity and Evenness Index}

Diatom species diversity index in Maluk Beach is classified as moderate, that is 1.964 . The sampling point II has the highest species diversity index with 2.039, and the sampling point I has the lowest species diversity index with 2.028 (Figure 3). Further, evenness index of diatom species in Maluk Beach is 0.522 (uneven distribution). The highest species evenness index is at sampling point I with 0.881 , and the lowest is at sampling point III with 0.581 (Figure 3). The air temperature at the sampling point $\mathrm{I}$ is the tolerance limit of diatom species to the ambient temperature for the place to live, namely $28^{\circ} \mathrm{C}$.
The overall species diversity index value is 1.964, which is categorized as medium. This relates to the adaptation of each species to the salinity of seawater $29 \%$ and the $\mathrm{pH}$ of seawater amounting to 7 . The classification is based on [15], in which if $\mathrm{H}^{\prime}<1.0$, species diversity is categorized as low, low productivity as an indication of the existence of heavy pressure and unstable ecosystem. If the value is $1.0<\mathrm{H}^{\prime}<3.322$, it is categorized as moderate diversity, sufficient productivity, ecosystem condition is quite balanced, moderate ecological pressure. If $\mathrm{H}^{\prime}>$ 3.322 , it is categorized as high diversity, good ecosystem stability, high productivity, resistant to ecological pressure.
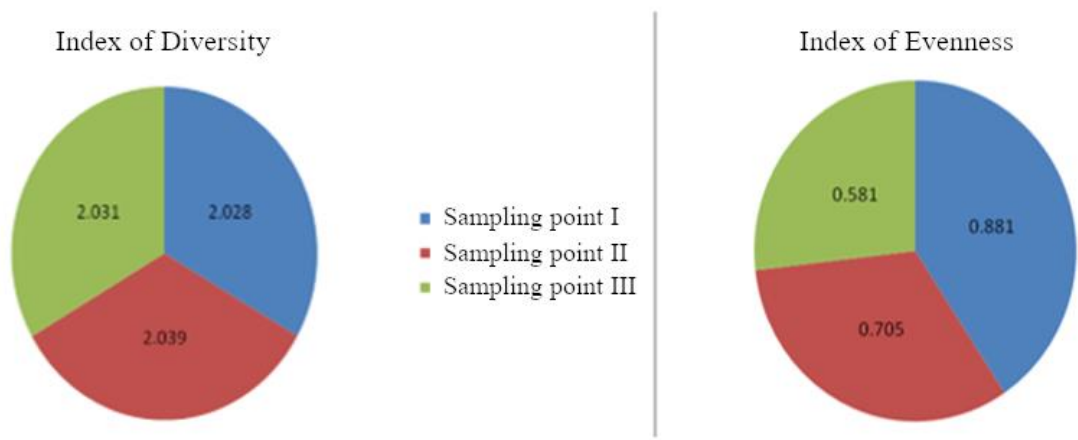

Fig. 3. Comparison of Diversity and Evenness Indexes of Diatom Species

The Evenness of diatom species in Maluk coastal waters is 0.522 . According to [16], if evenness is close to zero, the evenness between species is low and, in contrast, evenness of species that is close to one can be said to be even or equal. The low index of evenness for diatom species in Maluk Beach at the sampling point which has a high density indicates that there are several species that dominate with a large number of individuals. All types of organisms such as plants, diatoms can be bio-indicators for their environment [17].

\section{The Value of Importance}

The species value of importance for members of the Bacillarophyceae class from the three study sampling points was significantly different. The species that has the highest value of importance with $40.751 \%$ is Asteroplanus karianus. This is because the species A. karianus was found with the highest amount of density with 573,333 ind / L, compared to other diatom species. Whereas Camphylodiscus undulatus, Cocconeis scutellum, Grammatophora marina, Hantschia amphioxys, Mastogloia decussata, Navicula membranacea, Navicula cancellata, Nitzchia frequens, Odontella aurita, Rhabdonema adriaticum, Mastogloia decussata, Navicula membranacea, Navicula cancellata, Nitzchia frequens, Odontella aurita, Rhabdonema adriaticum, Mastogloia decussata, Navicula membranacea, Navicula cancellata, Nitzchia frequens, Odontella aurita, Rhabdonema adriaticum, Mastogloia decussata, Navicula membranacea, Navicula cancellata, Nitzchia frequens, Odontella aurita, Rhabdonema adriaticum, Mastogenous decussata, Navicula membranacea, Navicula cancellata, Nitzchia frequens, Odontella aurita, Rhabdonema adriaticum, Rhizosolenia alata, coral specula, and triceratium reticulum have the lowest value of importance with $1.848 \%$.

\section{CONCLUSION}

Based on the results of the study, it was concluded that the diatom community structure in the Maluk Coastal Waters are: (1) There were 38 species identified with a density of 1600 ind / L. (2). The diatom species diversity index was 1.946. (3) The evenness index of diatom species was 0.522. (4) The Species that have the highest value of importance were Asteroplanus karianus with 40.751\%, while those of Chaetoceros decipiens Camphylodiscus undulatus, Cocconeis scutellum, Grammatophora marina, Hantschia amphioxys, Mastogloia decussata, Navicula membranacea, Navicula cancellata, Nitzchia Frequens, Odontella aurita, Rhabdonema adriaticum, Rhizolenia alata, and Triceratium reticulum have the lowest value of importance with $1.848 \%$.

\section{REFERENCES}

[1] Roito, M., Y.I., Siregar dan Mubarak. 2014. Analisis Struktur Komunitas Diatom Planktonik Di Perairan Pulau Topang Kabupaten Kepulauan Meranti Provinsi Riau. Jurnal Perikanan Dan Kelautan, 19 (2): 23-32.

[2] Siregar, S.H., A., Mulyadi dan O.J., Hasibuan. 2008. Struktur Komunitas Diatom (Bacillariophyceae) Pada Lambung Kapal Di Perairan Dumai Provinsi Riau. Journal of Enfirotmental Science, 2(2): 33-47.

[3] Soeprobowati, T.R. 2011. Variabilitas Keanekaragaman dan Distribusi Vertikal Diatom Danau Rawa Pening. Jurnal Sains dan Matematika, 19(3): 65-70.

[4] Japa, L., Suripto, dan Mertha, I.G. 2013. Hubungan Kuantitatif Fitoplankton Dan Zooplankton Perairan Suaka Perikanan Gili Ranggo Teluk Serewe Lombok Timur. Jurnal Biologi Tropis, 13(1): 45-54.

[5] Cupp, E.E. 1943. Marine Plankton Diatoms of The West Coast of North America. USA: University of California Press. 
[6] Buff, D. H dan M., M., Bayer. 2002. Automatic Diatom Identification. USA: World Scientific Publishing.

[7] Al-Kandari, M., F. Y. Al-Yamani, dan K. Al-Rifaie. 2009. Marine Phytoplankton Atlas of Kuwait's Waters. Kuwait: Kuwait Institute for Scientific Research.

[8] Kim, Chong-cun. 2010. Algal Flora of Korea: Freshwater Diatims I. Korea: Junghaengsa, Inc.

[9] Park, J. G. 2012. Algal Flora of Korea. Volume 5 Number 1. Cyanophyta: Cyanophyceae: Chroococcales, Oscillatoriales Freshwater Cyanoprokaryota I. Korea: Junghaengsa, Inc.

[10] Hasanah, N. 2017. Keanekaragaman Dan Kelimpahan Diatom (Bacillariophyceae) Di Pantai Jeranjang Desa Taman Ayu Kecamatan Gerung Kabupaten Lombok Barat. Skripsi. Mataram: Universitas Mataram.

[11] Khairuddin dan L., Japa. 2014. Komunitas Fitoplankton Perairan Pantai Utara, Timur, Dan Selatan Pulau Lombok. Jurnal Biologi Tropis, 14(2): 100-107.

[12] Aini, Y.Q., A., Al Idrus, dan L., Japa. 2018. Komunitas Plankton Pada Perairan Habitat Mangrove di Gili Sulat Lombok Timur. Prosiding Seminar Nasional Pendidikan Biologi, 32-40.

[13] Yamaguchi, H., M., Minamida, T., Matsubara, dan K., Okamura. 2014. Novel Blooms of The Diatom Asteroplanus karianus Nutrients from Ariake Sea Coastal Waters. MEPS, 517(1):51-60.

[14] Shikata, T., T., Matsubara, M., Yoshida, S., Sakamoto, M., Yamaguchi. 2015. Effects Of Temperature, Salinity, And Photosynthetic Photon flux Density On The Growth Of The Harmful Diatom Asteroplanus karianus in the Ariake Sea, Japan. Japanese Society of Fisheries Science, 81 (6): 1063-1069.

[15] Hidayat, T. 2017. Kelimpahan dan Struktur Komunitas Fitoplankton Pada Daerah yang Di Reklamasi Pantai Seruni Kabupaten Bantaeng. Skripsi. Makassar: Universitas Hasanuddin.

[16] Choirun, A., S. H. J. Sari dan F. Iranawati. 2015. Identifikasi Fitoplankton Spesies Harmfull Algae Bloom (HAB) Saat Kondisi Pasang di Perairan Pesisir Brondong, Lamongan, Jawa Timur. Jurnal Ilmu Kelautan dan Perikanan, 25 (2): 58-66.

[17] Khairuddin, Yamin, M., dan Syukur, A. 2018. Analisis Kualitas Air Kali Ancar dengan Menggunakan Bioindikator Makroinvertebrata. Jurnal Biologi Tropis, Juli - Desember 2016 : Volume 16 (2) [10 -22]. DOI: 10.29303/jbt.v16i2.220 